Article

\title{
Triterpenes and Aromatic Meroterpenoids with Antioxidant Activity and Neuroprotective Effects from Ganoderma lucidum
}

\author{
Cuifang Wang ${ }^{1, *}$, Xuemin Liu ${ }^{2}$, Chenlei Lian ${ }^{2}$, Jiaying Ke ${ }^{1}$ and Jieqing Liu ${ }^{2, *}$ \\ 1 College of Oceanology and Food Science, Quanzhou Normal University, Quanzhou 362000, China; \\ kejiaying2003@e-mail.com \\ 2 School of Medicine, Huaqiao University, Quanzhou 362021, China; liuxuemin@hqu.edu.cn.com (X.L.); \\ liancl@hqu.edu.cn (C.L.) \\ * $\quad$ Correspondence: wangcuifang@qztc.edu.cn (C.W.); liujieqing@hqu.edu.cn (J.L.); Tel.: +86-0595-2297-9207 (C.W.)
}

Received: 31 October 2019; Accepted: 25 November 2019; Published: 28 November 2019

\begin{abstract}
Reactive oxygen/nitrogen species generated in the human body can cause oxidative damage associated with many degenerative diseases such as atherosclerosis, dementia, coronary heart diseases, aging, and cancer. There is a great interest in developing new antioxidants from Ganoderma fungus due to its low toxicity. As part of our ongoing search for antioxidative constituents from the fruiting bodies of Ganoderma lucidum, the chemical constituents were investigated and seven secondary metabolites, including one new lanostane triterpene (1), two known aromatic meroterpenoids (6-7), and four known triterpenes (2-5), were isolated by a series of chromatographic methods. The structures of the seven compounds were elucidated by spectroscopic techniques. The isolated compounds were tested in vitro for antioxidant potencies and neuroprotective activities against $\mathrm{H}_{2} \mathrm{O}_{2}$ and aged $A \beta$-induced cell death in SH-SY5Y cells. As a result, compounds 1, 6, and 7 exhibited potent antioxidant and neuroprotective activities. Additionally, all isolated compounds were tested for radical scavenging activities. Compounds $\mathbf{6}$ and $\mathbf{7}$ showed the comparable free radical scavenging activities with the standard drug in both ABTS (2, 2'-azobis (3-ethylbenzothiazole-6-sulfonaic acid)) and ORAC (oxygen radical absorbance capacity) experiments. The results from this study suggested that G. lucidum and its metabolites (especially the meroterpenoids) may be potential functional food ingredients for the antioxidation and prevention of neurogenerative diseases.
\end{abstract}

Keywords: antioxidant activity; Ganoderma lucidum; methyl ganoderate G1; neuroprotective effects

\section{Introduction}

Reactive oxygen species (ROS) can cause extensive damage to DNA, proteins, and lipids. This could be the fundamental cause of aging and many other important diseases such as cancer, cardiovascular diseases, and neurogeneration [1]. Deposition of different physicochemical forms of amyloid $\beta$ peptide $(A \beta)$ constitutes a major neuropathological hallmark of Alzheimer's disease [2]. Several lines of evidence suggest that $A \beta$ may exert its pathological effects in the central nervous system at least in part through ROS-mediated mechanisms [3,4]. Owing to the increased demand for and importance of antioxidants in day-to-day life, the search for effective, nontoxic, natural compounds with antioxidant activity has increasingly become a matter of interest.

A large number of medicinal mushrooms have recently been reported to possess significant antioxidant activity [5,6]. Ganoderma lucidum is known as the "mushroom of immortality" and considered to be a panacea to cure all kinds of diseases in Chinese folklore. As demonstrated by the numerous publications, polysaccharides are important contributors to the antioxidant 
properties reported for Ganoderma species [7-9]. Recently, research found that the total phenols of Ganoderma lucidum also showed significant antioxidant activity [10]. Several meroterpenoids from Ganoderma cochlear and Ganoderma capense were isolated for their antioxidant activities [11,12]. The aromatic meroterpenoids have attracted the attention of many phytochemists, chemists, and pharmocologists, due to their diverse structures and significant bioactivities (antioxidant, anti-HIV protease, and antifibrotic activities) [13-16]. Meanwhile, some oxygenated lanostane triterpenoids also showed potent free radical scavenging activities and neuroprotective activity $[17,18]$. These previous studies suggested Ganoderm mushrooms might be a novel resource for natural antioxidant exploration.

Our group has long been interested in Ganoderma species [19-21] and our previous studies showed that the total ethanol extract of G. lucidum displayed antioxidant activity. As part of our ongoing search for antioxidative constituents from this fungus, seven compounds, including a new lanostanoid, four known lanostainoids, and two known aromatic meroterpenoids, were isolated from the fruiting bodies of G. lucidum. Their antioxidant potencies were investigated in various systems. Meanwhile, compounds 1, 6, and 7 were evaluated for their neuroprotective properties. Our results will lay the foundation for the further in vivo bioactive research and provide a theoretical basis to the application of G. lucidum on antioxidation and antineurological disease.

\section{Results}

\subsection{Structure Elucidation of Compound 1}

The 95\% ethanol extracts of the fruiting bodies of G. lucidum were fractionated and purified by a series of chromatographic methods to obtain one new lanostanoid and six known compounds (1-7, Figure 1).

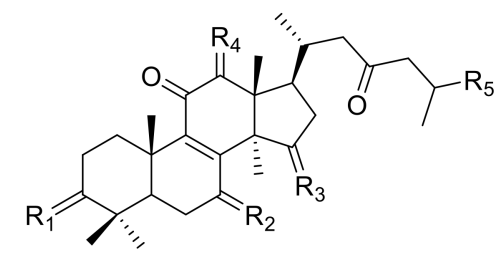

$1 \alpha-\mathrm{H} \beta-\mathrm{OH} \quad \alpha-\mathrm{H} \beta-\mathrm{OH} \quad \alpha-\mathrm{OH} \beta-\mathrm{H} \quad \alpha-1$

$2 \mathrm{O} \quad \alpha-\mathrm{H} \beta-\mathrm{OH} \quad \mathrm{O}$

$3 \alpha-\mathrm{H} \beta-\mathrm{OH} \quad \mathrm{O}$

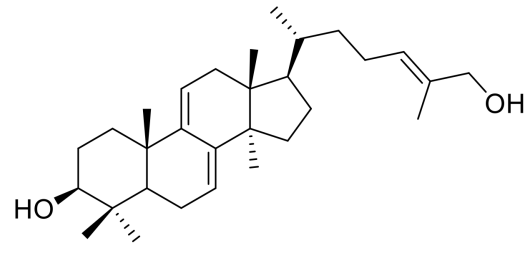

5
R4

$\alpha-\mathrm{H} \beta-\mathrm{OH}$

$\alpha-\mathrm{H} \beta-\mathrm{OCOCH} 3 \mathrm{COOH}$

$\mathrm{COOH}$

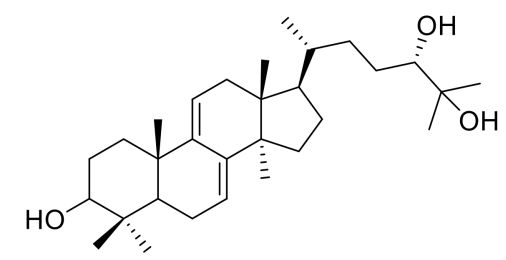

4
$\mathrm{COOCH} 3$<smiles>CC1=CCC(C(CC(=O)c2cc(O)ccc2O)C(=O)O)OC1</smiles>

$(+)-6$<smiles>CC1=CCC(C(CC(=O)c2cc(O)ccc2O)C(=O)O)OC1</smiles>

$(-)-7$

Figure 1. Structures of isolate compounds from Ganoderma lucidum.

Compound 1 was obtained as white powder $\left(\mathrm{CH}_{2} \mathrm{Cl}_{2}\right)$ with a molecular formula of $\mathrm{C}_{31} \mathrm{H}_{48} \mathrm{O}_{8}$ from the molecular ion peak $[\mathrm{M}+\mathrm{Na}]^{+}$at $\mathrm{m} / z 571.3241$ (calcd for $\mathrm{C}_{31} \mathrm{H}_{48} \mathrm{O}_{8} \mathrm{Na}$ 571.3247) in the high resolution electrospray ionization mass spectroscopy (HRESIMS). The ${ }^{1} \mathrm{H}$ nuclear magnetic resonance (NMR) spectrum (Table 1 ) of $\mathbf{1}$ showed the presence of five tertiary methyl signals at $\delta$ $0.86(\mathrm{~s}), 0.95(\mathrm{~s}), 1.04(\mathrm{~s}), 1.26(\mathrm{~s}), 1.27(\mathrm{~s})$, and two doublet methyl signals at $\delta 0.89(\mathrm{~d}, J=6.4 \mathrm{~Hz})$ and $1.19(\mathrm{~d}, J=7.1 \mathrm{~Hz})$. The ${ }^{13} \mathrm{C}$ NMR and distortionless enhancement by polarization transfer (DEPT) spectra (Table 1) of 1 revealed 31 carbon signals, including eight methyls, six methylenes, 
eight methines, and nine quaternary carbons (three carbonyls). These NMR characteristics were similar to those of methyl ganoderate G [22]. Comparison of the ${ }^{13} \mathrm{C}$ NMR data of 1 with those of methyl ganoderate $\mathrm{G}$ showed that the hydroxyl group $(\delta 72.48)$ in 1 replaced the carbonyl group ( $\delta$ 216.8) in methyl ganoderate $\mathrm{G}$ at $\mathrm{C}-15$, which was confirmed by the heteronuclear multiple bond correlation (HMBC) correlations of H-15 with C-16 and C-14; of Me-30 with C-15 (Figure S7 in Supplementary Material). In the rotating frame overhauser effect spectroscopy (ROESY) spectrum, cross-peak of H-3/H-5, H-5/H-7, Me-29/H-3, Me-30/H-12, and Me-18/H-15 indicated that 3-OH, 7-OH, $12-\mathrm{OH}$, and $15-\mathrm{OH}$ were $\beta$-oriented, $\beta$-oriented, $\beta$-oriented, and $\alpha$-oriented, respectively (Figure $\mathrm{S} 6$ in Supplementary Material). Thus, the structure of compound 1 was $3 \beta, 7 \beta, 12 \beta, 15 \alpha$-tetrahydroxy-11, 23-dioxo-5 $\alpha$-lanost-8-en-26-oate, named methyl ganoderate G1 (1).

Table 1. NMR spectroscopic data for compound 1 in $\mathrm{CDCl}_{3}$.

\begin{tabular}{|c|c|c|c|c|c|}
\hline \multirow{2}{*}{ Position } & \multicolumn{2}{|l|}{1} & \multirow{2}{*}{ Position } & \multicolumn{2}{|c|}{1} \\
\hline & $\delta_{H}(\mathrm{~J}$ in $\mathrm{Hz})$ & $\delta_{C}$ & & $\delta_{H}(\mathrm{~J}$ in $\mathrm{Hz})$ & $\delta_{C}$ \\
\hline \multirow[t]{2}{*}{1} & $1.68 \mathrm{~m}$ & 34.61 & 16 & $1.79 \mathrm{~m}$ & 36.25 \\
\hline & $2.75 \mathrm{~m}$ & & & $2.50 \mathrm{~m}$ & \\
\hline \multirow[t]{2}{*}{2} & $2.15 \mathrm{~m}$ & 28.28 & 17 & $1.81 \mathrm{~m}$ & 48.10 \\
\hline & & & 18 & $0.95 \mathrm{~s}$ & 17.12 \\
\hline 3 & $3.23 \mathrm{dd}(10.8,5.5)$ & 78.19 & 19 & $1.26 \mathrm{~s}$ & 19.38 \\
\hline 4 & - & 38.61 & 20 & $2.15 \mathrm{~m}$ & 32.63 \\
\hline 5 & $2.95 \mathrm{~m}$ & 49.07 & 21 & $0.89 \mathrm{~d}(6.4)$ & 19.62 \\
\hline \multirow[t]{2}{*}{6} & $1.64 \mathrm{~m}$ & 27.80 & 22 & $1.8 \mathrm{~m}$ & 49.72 \\
\hline & $2.13 \mathrm{~m}$ & & & & \\
\hline 7 & $4.57 \mathrm{dd}(10.3,7.2)$ & 69.52 & 23 & - & 208.53 \\
\hline 8 & - & 157.78 & 24 & $2.47 \mathrm{~m}$ & 46.72 \\
\hline 9 & - & 141.96 & & $2.83 \mathrm{~m}$ & \\
\hline 10 & - & 38.52 & 25 & $2.08 \mathrm{~m}$ & 34.61 \\
\hline 11 & - & 199.73 & 26 & - & 176.26 \\
\hline 12 & $4.14 \mathrm{~d}(2.3)$ & 77.22 & 27 & $1.19 \mathrm{~d}(7.1)$ & 17.09 \\
\hline 13 & - & 47.12 & 28 & $1.04 \mathrm{~s}$ & 28.15 \\
\hline 14 & - & 53.90 & 29 & $0.86 \mathrm{~s}$ & 15.67 \\
\hline \multirow[t]{2}{*}{15} & $4.76 \mathrm{t}(7.8)$ & 72.48 & 30 & $1.27 \mathrm{~s}$ & 19.48 \\
\hline & & & COOMe & $3.69 \mathrm{~s}$ & 51.91 \\
\hline
\end{tabular}

The known isolates were identified by comparing their physical and spectroscopic data with literature data. They were ganoderic acid D2 (2) [23], ganoderic acid H (3) [23], ludidumol B (4) [24], ganoderiol B (5) [25], lingzhine E (6) [26], and lingzhine F (7) [26], by comparison of their NMR data with those in the literature.

\subsection{Bioactivity Evaluation}

\subsubsection{ABTS ${ }^{+}$Radical Scavenging Assay}

The ABTS ${ }^{+}$assay is an excellent tool for determining the antioxidant activity of hydrogen-donating antioxidants and of chain-breaking antioxidants [27]. In the present study, the ability of test samples to scavenge ABTS was assessed on the basis of their $\mathrm{EC}_{50}$ values, defined above as an effective concentration at which the ABTS radical was scavenged by $50 \%$. $\mathrm{EC}_{50}$ values of the isolates and trolox (used as a reference compound) are given in Table 2. A low $\mathrm{EC}_{50}$ value indicates strong antioxidant activity in a tested sample. Among these compounds, lingzhine E (6) and lingzhine F (7) showed comparable ABTS.+ scavenging effects with $\mathrm{EC}_{50}$ values of $0.59 \pm 0.15$ and $0.27 \pm 0.05 \mathrm{mM}$, respectively, which was close to the positive control (trolox) with an $\mathrm{EC}_{50}$ value of $0.42 \pm 0.03 \mathrm{mM}$. 
Table 2. ABTS ${ }^{+}$radical scavenging activity and ORAC values of compounds 1-7 $(n=6)$.

\begin{tabular}{ccc}
\hline \multirow{2}{*}{ Samples } & \multicolumn{2}{c}{ Antioxidant Capacity } \\
\cline { 2 - 3 } & $\begin{array}{c}\text { ABTS Radical Scavenging Assay } \\
\left(\text { EC }_{\mathbf{5 0}} \pm \mathbf{S D}, \mathbf{m M}\right)\end{array}$ & $\begin{array}{c}\text { ORAC Value }(\boldsymbol{\mu m o l ~ T E} / \boldsymbol{\mu m o l}) \\
(\mathbf{m e a n} \pm \mathbf{S D})\end{array}$ \\
\hline $\mathbf{1}$ & $1.12 \pm 0.17$ & $1.35 \pm 0.25$ \\
$\mathbf{2}$ & $2.32 \pm 0.16$ & $0.36 \pm 0.14$ \\
$\mathbf{3}$ & $2.18 \pm 0.15$ & $0.25 \pm 0.18$ \\
$\mathbf{4}$ & $1.64 \pm 0.18$ & $0.51 \pm 0.12$ \\
$\mathbf{5}$ & $1.85 \pm 0.14$ & $0.59 \pm 0.18$ \\
$\mathbf{6}$ & $0.59 \pm 0.15$ & $5.42 \pm 0.20$ \\
$\mathbf{7}$ & $0.27 \pm 0.05$ & $7.24 \pm 0.15$ \\
Trolox & $0.42 \pm 0.03$ & - \\
Quercetin & - & $7.78 \pm 0.27$ \\
\hline
\end{tabular}

\subsubsection{ORAC Antioxidant Activity Assay}

ORAC is also a widely used in vitro antioxidant capacity assay [28]. It is a chemical antioxidant assay that is based on the inhibition of the peroxyl-radical induced oxidation initiated by the thermal decomposition of 2, 2'-azobis-(2-amidinopropane) dihydrochloride (AAPH). The antioxidant capacity of the isolates was also measured by ORAC assay and the potency of the natural compound was compared with that of the positive control, quercetin, which is well known for its use as an antioxidant. The ORAC results are expressed as trolox equivalent [4] and shown in Table 2. A high ORAC value indicates strong antioxidant activity in a tested sample. Among the seven compounds, the more potent radical scavenger was lingzhine $\mathrm{E}(7)(7.24 \pm 0.27 \mu \mathrm{mol} \mathrm{TE} / \mu \mathrm{mol})$ with a similar value to quercetin (7.78 $\pm 0.27 \mu \mathrm{mol} \mathrm{TE} / \mu \mathrm{mol})$, followed by lingzhine (6) $(5.42 \pm 0.20 \mu \mathrm{mol} \mathrm{TE} / \mu \mathrm{mol})$. This result was consistent with those of the ABTS assay.

\subsubsection{Antioxidant Effects on $\mathrm{H}_{2} \mathrm{O}_{2}$-Induced ROS Production in SH-SY5Y Cells}

The in vitro antioxidant assays, based on chemical reactions, are easy to operate and widely used to evaluate antioxidant capacities. However, their main disadvantage is that they do not reflect cellular physiological conditions. Therefore, a cell-based antioxidant activity assay to evaluate the antioxidant potential is necessary. ROS, such as the superoxide anion radical, hydrogen peroxide, and hydroxyl radical, are generated during many physiological and pathological processes and reported to function in an array of intracellular signaling cascades [29]. $\mathrm{H}_{2} \mathrm{O}_{2}$ is used extensively as an inducer of oxidative stress in vitro because its cellular actions and pathophysiological roles have been well studied [30]. SH-SY5Y human neuroblastoma cells are highly sensitive to oxidative stressors such as $\mathrm{H}_{2} \mathrm{O}_{2}$. The protective activity of compounds $1-7$ against $\mathrm{H}_{2} \mathrm{O}_{2}$-induced oxidative stress was evaluated on SH-SY5Y cells at the concentration of $40 \mu \mathrm{M}$. After incubation with $200 \mu \mathrm{M} \mathrm{H}_{2} \mathrm{O}_{2}$ for $12 \mathrm{~h}$, only $41.54 \pm 2.04 \%$ of cultured cells survived. Compounds 1, 6, and 7 (10-40 $\mu \mathrm{M})$ could protect $\mathrm{H}_{2} \mathrm{O}_{2}$-induced cell damage in a dose-dependent relationship, and the survival rates at $40 \mu \mathrm{M}$ were $62.68 \pm 2.81 \%, 72.57 \pm 2.12 \%$, and $78.96 \pm 1.86 \%$, respectively. Luteolin is used as positive control with a survival rate of $73.59 \pm 2.19 \%$ at $40 \mu \mathrm{M}$ (Figure 2). $2^{\prime},-7^{\prime}$-dichlorofluorescin diacetate (DCFH-DA) is one of the most widely used techniques for directly measuring the redox state of a cell. When SH-SY5Y cells were challenged with $200 \mu \mathrm{M} \mathrm{H}_{2} \mathrm{O}_{2}$, ROS were generated over twofold compared to the unchallenged control, while the treatment with compounds 1, 6, and 7 dose-dependently decreased the $\mathrm{H}_{2} \mathrm{O}_{2}$-mediated ROS formation (Figure 3). These results imply that methyl ganoderate G1 (1), lingzhine $\mathrm{E}$ (6), and lingzhine F (7) may have an ability to directly scavenger ROS and/or free radicals. 
A

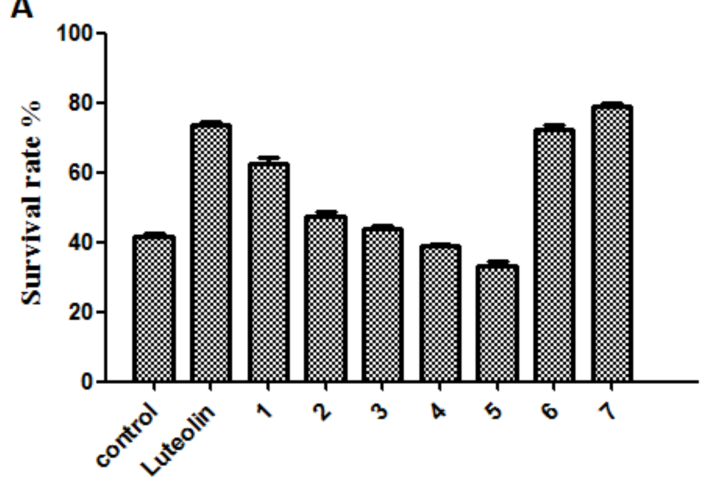

B

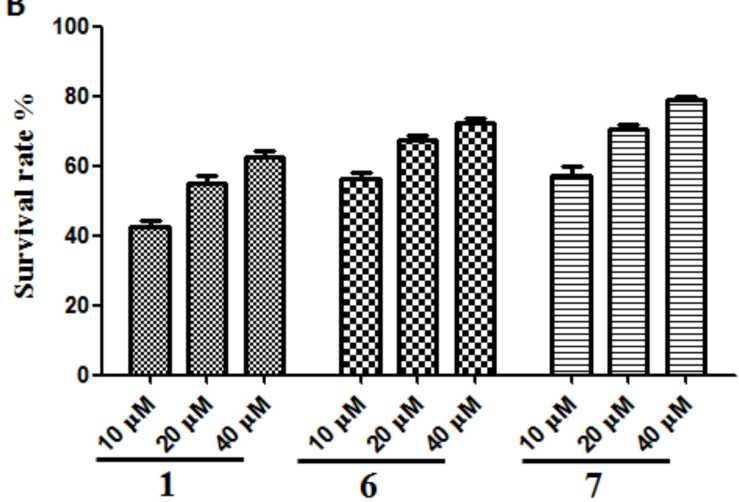

Figure 2. Effect of compounds 1-7 on $\mathrm{H}_{2} \mathrm{O}_{2}$-induced SH-SY5Y cell death. (A) 1-7: compounds 1-7 $40 \mu \mathrm{M}$; control: $200 \mu \mathrm{M} \mathrm{H}_{2} \mathrm{O}_{2}$ as negative control; Luteolin: $40 \mu \mathrm{M}$ luteolin as positive control; (B) the survival rate of compounds 1, 6, and 7 in different concentrations. Data represent the mean values of four experiments $\pm \mathrm{SD}$.

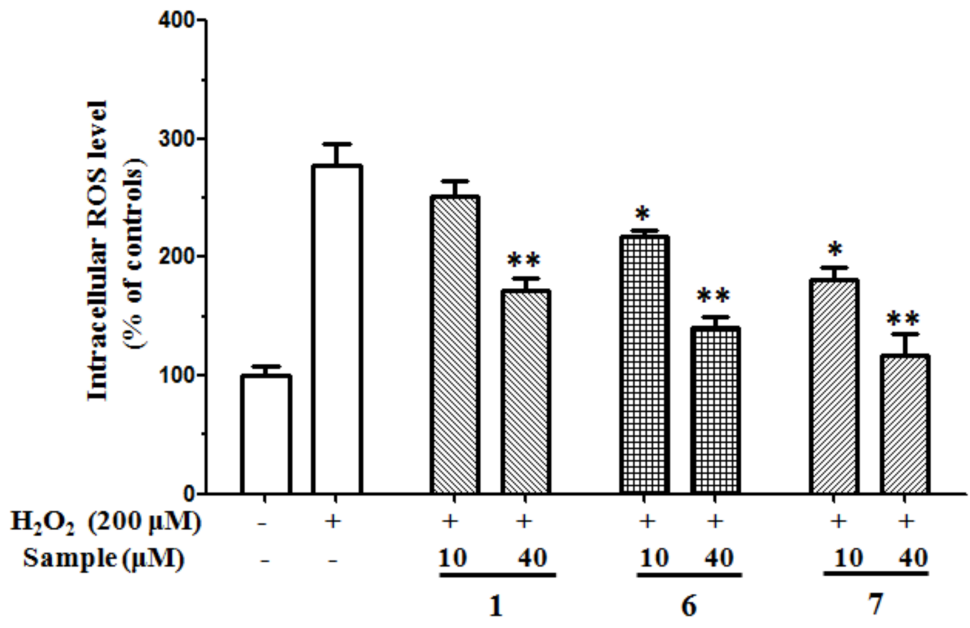

Figure 3. Effects of compounds 1, 6, and 7 on DCFH oxidation induced by $\mathrm{H}_{2} \mathrm{O}_{2}$ in SH-SY5Y cells. The columns represent $\%$ of change in fluorescence intensity with respect to $\mathrm{H}_{2} \mathrm{O}_{2}$-treated cells. All data were expressed as mean \pm S.D., $n=4$. ${ }^{* *} p<0.01,{ }^{*} p<0.05$ compared with $\mathrm{H}_{2} \mathrm{O}_{2}$-treated control.

\subsubsection{Protection of SH-SY5Y Cells Against A $\beta$-Induced Damage}

There is abundant evidence suggesting that an excess of $A \beta$, which aggregates into toxic fibrillar deposits, plays a central role in the etiology of Alzheimer's disease (AD) [31]. In support of this hypothesis, numerous in vitro and in vivo studies have reported on the neurotoxic effects of $A \beta$-related fragments in neurons derived from regions severely affected in AD [32]. Although the precise mechanisms mediating the toxic properties of $A \beta$ have yet to be extensively understood, it has been proposed that they are associated with oxidative stress-dependent apoptosis [33]. Hence, the capacity of methyl ganoderate G1 (1), lingzhine E (6), and lingzhine F (7) in protecting neuroblastoma SH-SY5Y cells against $A \beta$-induced damage was examined. $A \beta_{25-35}$, a synthetic peptide that possesses most of the physical and biological properties of full-length $A \beta$ and is often used to study the neuroprotective effects of various compounds, was predicted to modulate $A \beta$ toxicity in vitro [34]. In this study, the neuroprotective activity of compounds 1,6 , and 7 against $A \beta$-induced oxidative stress was evaluated on SH-SY5Y cells. After incubation with $25 \mu \mathrm{M}$ aged $\mathrm{A} \beta_{25-35}$ for $24 \mathrm{~h}$, only $63.43 \pm 4.81 \%$ of cultured cells survived. Treatment of compounds 1, 6, and $7(10-40 \mu \mathrm{M})$ could protect $A \beta$-induced cell damage in a dose-dependent relationship, and the survival rates at $40 \mu \mathrm{M}$ were $72.4 \pm 3.19 \%$, $77.11 \pm 4.18 \%$, and $80.17 \pm 5.19 \%$, respectively (Figure 4 ). 


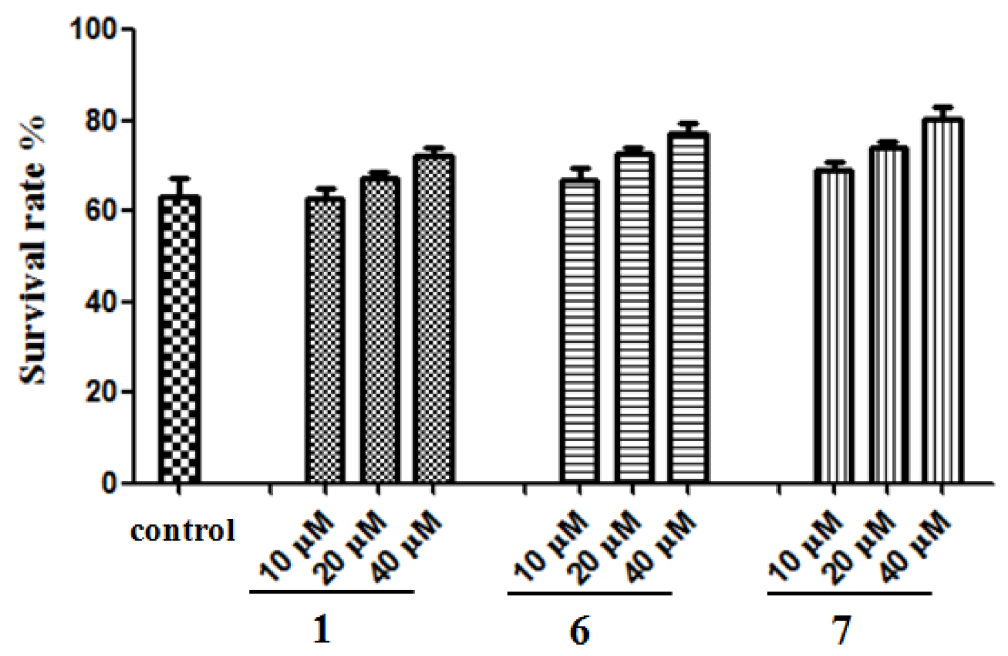

Figure 4. Effect of compounds 1, 6, and 7 on aged $A \beta_{25-35}$-induced SH-SY5Y neurotoxicity. Control: $25 \mu \mathrm{M}$ aged $\mathrm{A} \beta_{25-35}$ as negative control. Data represent the mean values of four experiments $\pm \mathrm{SD}$.

\subsubsection{Inhibition of ROS Generation Induced by $A \beta_{25-35}$ in SH-SY5Y Cells}

The neurotoxicity of $A \beta$ has been reported to be mediated with oxygen free radicals and attenuated by antioxidants and free radical scavengers. Many reports have demonstrated the involvement of ROS formation in $A \beta$-induced neurotoxicity [35]. We investigated whether compounds $\mathbf{1}, \mathbf{6}$, and $\mathbf{7}$ affect ROS formation by A $\beta$ using DCFH-DA probe staining. As shown in Figure 5, exposure to A $\beta$ induced an elevation of the intracellular ROS levels. Treatment with compounds $\mathbf{1 , 6}$, and $\mathbf{7}$ ameliorated the intracellular ROS elevation. These results indicated that methyl ganoderate G1 (1), lingzhine E (6), and lingzhine $F(7)$ have the ability to scavenge $A \beta$-induced ROS increase.

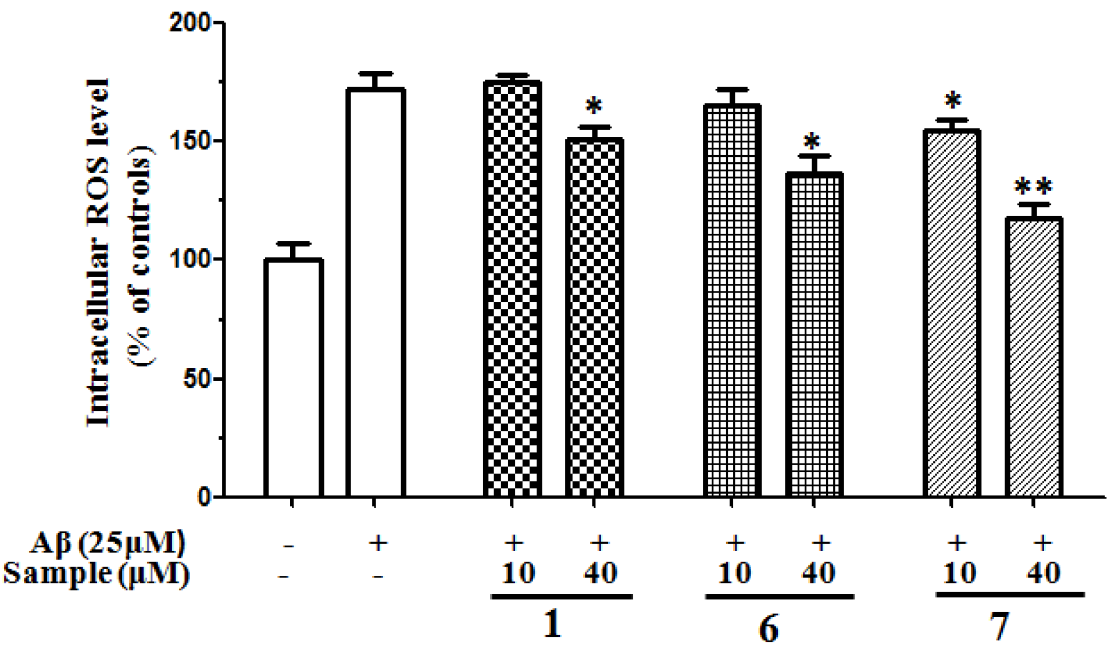

Figure 5. Effects of compounds 1, 6, and 7 on DCFH oxidation induced by A $\beta_{25-35}$ in SH-SY5Y cells. The columns represent $\%$ of change in fluorescence intensity with respect to $A \beta_{25-35}$-treated cells. All data were expressed as mean \pm S.D., $n=4 .{ }^{* *} p<0.01,{ }^{*} p<0.05$ compared with $\mathrm{A} \beta_{25}-35$-treated control.

\section{Discussion}

Since 2000, many structurally diverse aromatic meroterpenoids were found from different species of Ganoderma and have attracted the interest of chemists and pharmacologists $[11,15,26]$. In the present study, two aromatic meroterpenoids (6-7) were isolated and identified from the fruiting bodies of G. lucidum. Our previous and present research exhibited that aromatic meroterpenoids had 
excellent in vitro antioxidant effects [11]. Hence, the antioxidant potencies of the two compounds were first investigated employing various in vitro systems. The results showed that lingzhine E (6) and lingzhine F (7) had strong antioxidant activities. Moreover, the lanostanoid triterpenes obtained from the Ganoderma family have been reported to show strong antioxidant activities and neuroprotective activities $[17,18]$. Hence, the isolated compounds were evaluated in vitro for their antioxidant potencies and neuroprotective activities against $\mathrm{H}_{2} \mathrm{O}_{2}$ - and $\mathrm{A} \beta$-induced cell death in SH-SY5Y cells. Methyl ganoderate (1), lingzhine E (6), and lingzhine F (7) possessed significant neuroprotective activities. These results will lay the foundation for further in vivo bioactive research and provide a theoretical basis to the application of G. lucidum on antineurological disease.

\section{Materials and Methods}

\subsection{Materials and Reagent}

The fruiting bodies of G. lucidum were purchased from Wuyi Mountain Traditional Chinese Medicine Market in Fujian Province of China in June 2016. The mushroom was identified by Prof. Chen Tiqiang, who works at Fujian Academy of Agricultural Sciences.

ABTS detection kit and Cell Counting Kit (CCK-8) were purchased from Beyotime Institute of Biotechnology (Nanjing, China). 2, 2'-Azobis-(2-amidinopropane) dihydrochloride (AAPH), 6-hydroxy-2,5,7,8-tetramethylchroman-2-carboxylic acid (trolox), fluorescein sodium salt (FL), $2^{\prime}, 7^{\prime}$-dichlorofluorescein diacetate ( $\left.\mathrm{DCFH}_{2}-\mathrm{DA}\right)$, dimethyl sulfoxide (DMSO), and amyloid $\beta$-Protein Fragment 35-25 (A $\left.\beta_{25-35}\right)$ were purchased from Sigma-Aldrich, Inc. (St. Louis, MO, USA). Minimum essential media (MEM) and F12 were purchased from Gibco BRL (Life Technologies, China). Trypsin-EDTA and penicillin-streptomycin solution were acquired from Gibco BRL (Grand Island, NY, USA). Fetal bovine serum (FBS) was obtained from Corning (Mediatech, Manassas, VA, USA). The organic solvents used for fraction and separation were purchased from Sinopharm Chemical Reagent Co. Ltd. (Shanghai, China).

\subsection{Apparatus and Chemicals}

1D and 2D NMR spectra were recorded in $\mathrm{CDCl}_{3}$ using a Bruker AVANCE III-600 spectrometer (Bruker Corp., Switzerland), and tetramethyl silane (TMS) was used as an internal standard. Chemical shifts $(\delta)$ were expressed in ppm with reference to TMS. Optical rotations were obtained with a Jasco P-1020 polarimeter (Japan). HRESIMS spectral data were recorded on an ultra performance liquid chromatography-time of flight-mass spectrometry (UPLC-TOF-MS) Waters, MA, USA), carried out on Waters Acquity UPLC columns at $35^{\circ} \mathrm{C}$ (Zorbax eclipse plus C18: $2.1 \mathrm{~mm} \times 50 \mathrm{~mm}, 1.8 \mu \mathrm{m}$ ). Column chromatography was conducted using silica gel (Qingdao Marine Chemistry Company, China) and Sephadex LH-20 (Pharmacia, Sweden). Activity data were recorded on a microplate reader (Infinite M200 PRO, Tecan, Sweden).

\subsection{Extraction and Isolation}

The dried fruiting bodies of G. lucidum (30 kg) were powdered and extracted with 95\% ethanol three times at room temperature. After filtration and evaporation in vacuo, a residue was obtained, which was taken up in $\mathrm{H}_{2} \mathrm{O}$ and successively partitioned with petroleum ether (PE, three times) and ethyl acetate (EtOAc, three times). The EtOAc layer (1200 g) was absorbed on macroporous resin (D101) and subjected to column chromatography [MeOH: $\left.\mathrm{H}_{2} \mathrm{O}(1: 4,3: 2,4: 1,5: 0)\right]$ to give four main fractions (Fr.1-Fr.4). Fr.1 (400 g) was subjected to silica gel column chromatography with $\mathrm{CH}_{2} \mathrm{Cl}_{2} / \mathrm{MeOH}(100: 1$, 50:1, 20:1, 5:1) and divided into four fractions. The 50:1 fraction was applied to a chromatography column for isolation of 3 (5 mg). The 20:1 fraction was treated by Sephadex LH-20 (MeOH) and divided into three subfractions (Fr.A, Fr.B, and Fr.C). Fr.A was applied to a chromatography column for isolation of $2(8.8 \mathrm{mg})$. Fr.B was subjected to semipreparative $\mathrm{HPLC}\left(\mathrm{MeOH} / \mathrm{H}_{2} \mathrm{O}, 40 \%\right.$ to yield compound $6\left(31 \mathrm{mg}, \mathrm{t}_{\mathrm{R}}=9.85 \mathrm{~min}\right)$ and compound $\left.7\left(26 \mathrm{mg}, \mathrm{t}_{\mathrm{R}}=10.65 \mathrm{~min}\right)\right)$. The 5:1 fraction was also 
subjected to silica gel column chromatography and three subfractions were obtained (PE/acetone: 5:1, 2:1, 1:2). Compound $4(6.5 \mathrm{mg})$ and $5(8.5 \mathrm{mg})$ were isolated from the 2:1 fraction by repeated silica gel column chromatography $\left(\mathrm{CH}_{2} \mathrm{Cl}_{2} / \mathrm{MeOH}\right)$. Reverse phase silica gel ( $\mathrm{MeOH} / \mathrm{H}_{2} \mathrm{O}$, step gradient) was used to treat the 1:2 fraction to give $1(20.1 \mathrm{mg})$.

Methyl ganoderate G1 (1): $[\alpha]^{25}$ D -90 (c 0.11, MeOH); UV (MeOH); $\lambda \max (\log \varepsilon): 253$ (4.05) nm. IR (KBr) vmax 3425, 2972, 1720, 1629, $1461 \mathrm{~cm}^{-1} ;{ }^{1} \mathrm{H}$ and ${ }^{13} \mathrm{C}$-DEPT data: see Table 1 . HRESIMS $m / z$ 571.3241 (calcd for $\mathrm{C}_{31} \mathrm{H}_{48} \mathrm{O}_{8} \mathrm{Na}$ 571.3247).

\subsection{Bioactivity Evaluation}

\subsubsection{ABTS Radical Cation Scavenging Activity}

ABTS radical cation scavenging activity was assayed according to instructions by the Beyotime Institute of Biotechnology. The stock solutions included ABTS solution and oxidant solution. The working solution was prepared by mixing the two stock solutions in equal quantities and allowing them to react for $16 \mathrm{~h}$ at room temperature in the dark. The solution was then diluted by mixing $1 \mathrm{~mL}$ working solution with $90 \mathrm{ml} 80 \%$ ethanol in order to obtain an absorbance of $0.7 \pm 0.05$ at $734 \mathrm{~nm}$. A fresh ABTS solution was prepared for each assay. Samples $(10 \mu \mathrm{L})$ with a concentration range of $0.05-3.00 \mathrm{mM}$ were mixed with $200 \mu \mathrm{L}$ of fresh ABTS solution and the mixture was left at room temperature for $6 \mathrm{~min}$. The absorbance was then measured at $734 \mathrm{~nm}$. Trolox was used as a reference compound. The radical scavenging activity of each sample was expressed in terms of the $\mathrm{EC}_{50}$ (the effective concentration at which $\mathrm{ABTS}^{+}$radicals were scavenged by $50 \%$ ), which was calculated from the log-dose inhibition curve.

\subsubsection{Oxygen Radical Absorbance Capacity Assay (ORAC Assay)}

The ORAC assay was carried out based on the previously described procedure with slight modification [36]. In brief, the sample/blank $(175 \mu \mathrm{L})$ was dissolved in phosphate buffer saline (PBS) at the concentration of $160 \mu \mathrm{g} / \mathrm{mL}$ at $\mathrm{pH}$ 7.4. The trolox standard was prepared in serial dilutions starting from $75 \mathrm{mM}$. Standard 96-well black microplates were used for the assay, and $25 \mu \mathrm{L}$ each of the samples, standard (trolox), blank (solvent/PBS), or positive control (quercetin) were added to the wells. Fluorescent sodium salt solution was added at $150 \mu \mathrm{L}$ per well, followed by incubation at $37^{\circ} \mathrm{C}$ for $45 \mathrm{~min}$. The total volume of each well was made up to $200 \mu \mathrm{L}$ by adding 2, 20-azobis-(2-amidinopropane) dihydrochloride $(\mathrm{AAPH})$ solution. Fluorescence value was recorded at $37^{\circ} \mathrm{C}$ (excitation at $485 \mathrm{~nm}$, emission at $535 \mathrm{~nm}$ ) using a fluorescence spectrophotometer (Infinite M200 PRO) equipped with an automatic thermostatic autocell holder. Data were collected every $2 \mathrm{~min}$ for $2 \mathrm{~h}$ and the data analysis was subsequently done by calculating the differences of AUC between the blank and the sample. Results were expressed as $\mu \mathrm{mol}$ of Trolox Equivalent/ $\mu \mathrm{mol}$ of pure compound.

\subsubsection{Cell Culture}

The human neuroblastoma cell line (SH-SY5Y) was obtained from Shanghai Institute of Cell Biology, Chinese Academy of Sciences. SH-SY5Y cells were cultured in MEM/F12 (1:1) medium supplemented with $10 \%$ FBS and $1 \%$ penicillin-streptomycin at $37^{\circ} \mathrm{C}$ and $5 \% \mathrm{CO} 2$.

\subsubsection{Cytoprotective Effects of Compounds 1-7 in SH-SY5Y}

Compounds 1-7 were dissolved in DMSO for use (DMSO in each well was less than 0.1\%). Before treatment, $100 \mu \mathrm{L} \mathrm{SH-SY5Y} \mathrm{cells} \mathrm{were} \mathrm{seeded} \mathrm{on} \mathrm{a} \mathrm{96-well} \mathrm{plate} \mathrm{at} \mathrm{the} \mathrm{density} \mathrm{of} 1 \times 10^{5}$ cells $/ \mathrm{mL}$ and cultured for $24 \mathrm{~h}$. The medium was changed to $99 \mu \mathrm{L}$ fresh medium containing $200 \mu \mathrm{M} \mathrm{H}_{2} \mathrm{O}_{2}$, and then cells were treated with $1 \mu \mathrm{L}$ different concentrations of compounds 1-7 for $12 \mathrm{~h}$. CCK-8 solution $(10 \mu \mathrm{L})$ was added to every well, and coincubated for $2 \mathrm{~h}$ at $37^{\circ} \mathrm{C}$. The absorbance was measured at $450 \mathrm{~nm}$ using a TECAN microplate reader. 


\subsubsection{Neuroprotective Effects of Compounds 1, 6, and 7 in SH-SY5Y}

Compounds 1, 6, and 7 were dissolved in DMSO for use (DMSO in each well was less than $0.1 \%$ ). Before treatment, $100 \mu \mathrm{L}$ SH-SY5Y cells were seeded on a 96-well plate at the density of $1 \times 10^{5}$ cells $/ \mathrm{mL}$ and cultured for $24 \mathrm{~h}$. The medium was changed to $99 \mu \mathrm{L}$ fresh medium containing $25 \mu \mathrm{M}$ aged $\mathrm{A} \beta_{25-35}$, and then cells were treated with $1 \mu \mathrm{L}$ different concentrations of compounds $\mathbf{1}, \mathbf{6}$, and $\mathbf{7}$ for $24 \mathrm{~h}$. CCK-8 solution $(10 \mu \mathrm{L})$ was added to every well, and coincubated for $2 \mathrm{~h}$ at $37^{\circ} \mathrm{C}$. The absorbance was measured at $450 \mathrm{~nm}$ using a Bio-Rad microplate reader.

\subsubsection{Measurement of Intracellular ROS Level}

The generation of intracellular reactive oxygen species (ROS) was measured using the DCFH-DA method [37]. Briefly, SH-SY5Y cells were cultured in 96-well plates $\left(1 \times 10^{4}\right.$ cells per well). Drug treatment, $\mathrm{H}_{2} \mathrm{O}_{2}$ stimulation, and $\mathrm{A} \beta_{25-35}$ stimulation were carried out as described in Sections 4.4.4 and 4.4.5. The cells were washed with warm PBS and were incubated with DCFH-DA for $30 \mathrm{~min}$ at $37^{\circ} \mathrm{C}$ in darkness. After the cells were washed twice with PBS, the fluorescence intensity was measured at an excitation wavelength of $485 \mathrm{~nm}$ and an emission wavelength of $538 \mathrm{~nm}$. The level of intracellular ROS was expressed as a percentage of value against the nontreated control group.

\subsubsection{Statistical Analysis}

Data analysis was performed using GraphPad Prism 6.0 software (GraphPad Software, San Diego, USA). All results are presented as the mean \pm S.D. and a two-tailed test or a one-way analysis of variance (ANOVA) was used to determine the statistical significance. Differences were considered to be significant for $p$-value $<0.05$.

Supplementary Materials: The following are available online at http://www.mdpi.com/1420-3049/24/23/4353/s1, Figure S1. ${ }^{1} \mathrm{H}$ NMR spectrum of compound $\mathbf{1}$ in $\mathrm{CDCl}_{3}$; Figure S2. ${ }^{13} \mathrm{C}$ NMR spectrum of compound $\mathbf{1}$ in $\mathrm{CDCl}_{3}$; Figure S3. DEPT spectrum of compound 1 in $\mathrm{CDCl}_{3}$; Figure S4. ${ }^{1} \mathrm{H}_{-}{ }^{1} \mathrm{H}$ COSY spectrum of compound $\mathbf{1}$ in $\mathrm{CDCl}_{3}$; Figure S5. HSQC spectrum of compound $\mathbf{1}$ in $\mathrm{CDCl}_{3}$; Figure S6. ROESY spectrum of compound $\mathbf{1}$ in $\mathrm{CDCl}_{3}$; Figure S7. HMBC spectrum of compound 1 in $\mathrm{CDCl}_{3}$.

Author Contributions: Formal analysis, C.L.; Investigation, C.W., C.L., X.L., and J.K.; Supervision, C.W. and J.L.; Writing—original draft, C.W. and J.L.

Funding: This work was financially supported by the Fujian Education Scientific Research Project for Young Teachers (No. JAT170485); the Quanzhou Science and technology plan project (2018C072R); the Fujian Provincial Natural Science Foundation of China (2018J01126); the Fundamental Research Funds for the Central Universities (ZQN-PY318).

Conflicts of Interest: The authors declare no conflict of interest.

\section{References}

1. Krishnaiah, D.; Sarbatly, R.; Bono, A. Phytochemical antioxidants for health and medicine a move towards nature. Biotechnol. Mol. Biol. Rev. 2007, 2, 97-104.

2. Selkoe, D.J. Developing preventive therapies for chronic diseases: Lessons learned from Alzheimer's disease. Nutr. Rev. 2007, 65, S239-S243. [CrossRef] [PubMed]

3. Ding, Q.; Dimayuga, E.; Keller, J.N. Oxidative damage, protein synthesis, and protein degradation in Alzheimer's disease. Curr. Alzheimer Res. 2007, 4, 73-79. [CrossRef] [PubMed]

4. Butterfield, D.A.; Drake, J.; Pocernich, C.; Castegna, A. Evidence of oxidative damage in Alzheimer's disease brain: Central role for amyloid $\beta$-peptide. Trends Mol. Med. 2001, 7, 548-554. [CrossRef]

5. Mathew, J.; Sudheesh, N.P.; Rony, K.A.; Smina, T.P.; Janardhanan, K.K. Antioxidant and antitumor activities of cultured mycelium of culinary-medicinal paddy straw mushroom Volvariella volvacea (Bull.: Fr.) singer (agaricomycetideae). Int. J. Med. Mushrooms 2008, 10, 139-148. [CrossRef]

6. Nitha, B.; De, S.; Adhikari, S.; Devasagayam, T.; Janardhanan, K. Evaluation of free radical scavenging activity of morel mushroom, Morchella esculenta mycelia: A potential source of therapeutically useful antioxidants. Pharm. Bio. 2010, 48, 453-460. [CrossRef] 
7. Chen, Y.; Xie, M.Y.; Nie, S.P.; Li, C.; Wang, Y.X. Purification, composition analysis and antioxidant activity of a polysaccharide from the fruiting bodies of Ganoderma atrum. Food Chem. 2008, 107, 231-241. [CrossRef]

8. Tseng, Y.H.; Yang, J.H.; Mau, J.L. Antioxidant properties of polysaccharides from Ganoderma tsugae. Food Chem. 2008, 107, 732-738. [CrossRef]

9. Liu, W.; Wang, H.; Pang, X.; Yao, W.; Gao, X. Characterization and antioxidant activity of two low-molecular-weight polysaccharides purified from the fruiting bodies of Ganoderma lucidum. Int. J. Bio. Macromol. 2010, 46, 451-457. [CrossRef]

10. Heleno, S.A.; Barros, L.; Martins, A.; Queiroz, M.J.R.; Santos-Buelga, C.; Ferreira, I.C. Fruiting body, spores and in vitro produced mycelium of Ganoderma lucidum from Northeast Portugal: A comparative study of the antioxidant potential of phenolic and polysaccharidic extracts. Food Res. Int. 2012, 46, 135-140. [CrossRef]

11. Peng, X.; Liu, J.; Wang, C.; Han, Z.; Shu, Y.; Li, X.; Zhou, L.; Qiu, M. Unusual prenylated phenols with antioxidant activities from Ganoderma cochlear. Food Chem. 2015, 171, 251-257. [CrossRef] [PubMed]

12. Peng, X.; Li, L.; Wang, X.; Zhu, G.; Li, Z.; Qiu, M. Antioxidant farnesylated hydroquinones from Ganoderma capense. Fitoterapia 2016, 111, 18-23. [CrossRef] [PubMed]

13. Peng, X.R.; Liu, J.Q.; Wan, L.S.; Li, X.N.; Yan, Y.X.; Qiu, M.H. Four new polycyclic meroterpenoids from Ganoderma cochlear. Org. Lett. 2014, 16, 4838-4841. [CrossRef]

14. Luo, Q.; Luo, Q.; Di, L.; Lu, Q.; Yan, Y.M.; Yang, Z.L.; Li, R.T.; Cheng, Y.X. Applanatumin A, a new dimeric Meroterpenoid from Ganoderma applanatum that displays potent antifibrotic activity. Org. Lett. 2015, 17, 1110-1113. [CrossRef]

15. Chen, D.; Liu, H.M.; Li, M.M.; Yan, Y.M.; Xu, W.D.; Li, X.N.; Cheng, Y.X.; Qin, H.B. Concise synthesis of ( \pm )-Lingzhiol via epoxy-arene cyclization. Chem. Commun. 2015, 51, 14594-14596. [CrossRef]

16. Dine, E.R.S.; El Halawany, A.M.; Ma, C.M.; Hattori, M. Inhibition of the dimerization and active site of HIV-1 protease by secondary metabolites from the Vietnamese Mushroom Ganoderma colossum. J. Nat. Prod. 2009, 72, 2019-2023. [CrossRef]

17. Chen, H.Y.; Zhang, J.J.; Ren, J.W.; Wang, W.Z.; Xiong, W.P.; Zhang, Y.D.; Bao, L.; Liu, H.W. Triterpenes and Meroterpenes with neuroprotective effects from Ganoderma leucocontextum. Chem. Biodivers. 2018, 15, 1-9. [CrossRef]

18. Qiu, J.M.; Wang, X.; Song, C.G. Neuroprotective and Antioxidant Lanostanoid Triterpenes from the Fruiting Bodies of Ganoderma atrum. Fitoterapia 2016, 109, 75-79. [CrossRef]

19. Wang, C.F.; Liu, J.Q.; Yan, Y.X.; Chen, J.C.; Lu, Y.; Guo, Y.H.; Qiu, M.H. Three new triterpenoids containing four-membered ring from the fruiting body of Ganoderma sinense. Org. Lett. 2010, 12, 1656-1659. [CrossRef]

20. Lian, C.; Wang, C.; Xiao, Q.; Xiao, L.; Xu, Y.; Liu, J. The triterpenes and steroids from the fruiting body Ganoderma duripora. Biochem. Syst. Ecol. 2017, 73, 50-53. [CrossRef]

21. Liu, J.Q.; Lian, C.L.; Hu, T.Y.; Wang, C.F.; Xu, Y.; Xiao, L.; Liu, Z.Q.; Qiu, S.Q.; Cheng, B.H. Two new farnesyl phenolic compounds with anti-inflammatory activities from Ganoderma duripora. Food Chem. 2018, 263, 155-162. [CrossRef] [PubMed]

22. Kikuchi, T.; Matsuda, S.; Murai., Y.; Ogita, Z. Ganoderic acid G and I and ganolucidic acid A and B, new triterpenoids from Ganoderma lucidum. Chem. Pharm. Bull. 1985, 33, 2628-2631. [CrossRef]

23. Kikuchi, T.; Kanomi, S.; Murai, Y.; Kadota, S.; Tsubono, K.; Ogita, Z. Constituents of the fungus Ganoderma lucidum (FR.) Karst. III. Structures of Ganolucidic acids A and B, new lanostane-type triterpenoids. Chem. Pharm. Bull. 1986, 34, 4030-4036. [CrossRef]

24. Li, P.; Deng, Y.P.; Wei, X.X.; Xu, J.H. Triterpenoids from Ganoderma lucidum and their cytotoxic activities. Nat. Prod. Res. 2013, 27, 17-22. [CrossRef] [PubMed]

25. Liu, J.; Shimizu, K.; Konishi, F.; Kumamoto, S.; Kondo, R. The anti-Androgen Effect of Ganoderol B (I)3 Isolated from the Fruiting Body of Ganoderma lucidum. Bioorgan. Med. Chem. 2007, 15, 4966-4972. [CrossRef] [PubMed]

26. Yan, Y.M.; Wang, X.L.; Luo, Q.; Jiang, L.P.; Yang, C.P.; Hou, B.; Zuo, Z.L.; Chen, Y.B.; Cheng, Y.X. Metabolites from the mushroom Ganoderma lingzhi as stimulators of neural stem cell proliferation. Phytochemistry 2015, 114, 155-162. [CrossRef]

27. Luo, J.; Li, L.; Kong, L. Preparative separation of phenylpropenoid glycerides from the bulbs of Lilium lancifolium by high-speed counter-current chromatography and evaluation of their antioxidant activities. Food Chem. 2012, 131, 1056-1062. [CrossRef] 
28. Kang, J.; Xie, C.; Li, Z.; Nagarajan, S.; Schauss, A.G.; Wu, T.; Wu, X. Flavonoids from acai (Euterpe oleracea Mart.) pulp and their antioxidant and anti-inflammatory activities. Food Chem. 2011, 128, 152-157. [CrossRef]

29. Fu, Y.; Chen, J.; Li, Y.J.; Zheng, Y.F.; Li, P. Antioxidant and anti-inflammatory activities of six flavonoids separated from licorice. Food Chem. 2013, 141, 1063-1071. [CrossRef]

30. Valko, M.; Leibfritz, D.; Moncol, J.; Cronin, M.T.; Mazur, M.; Telser, J. Free radicals and antioxidants in normal physiological functions and human disease. Int. J. Biochem. Cell. B 2007, 39, 44-84. [CrossRef]

31. Risacher, S.L.; Saykin, A.J. Neuroimaging and other biomarkers for Alzheimer's disease: The changing landscape of early detection. Annu. Rev. Clin. Psycho. 2013, 9, 621-648. [CrossRef] [PubMed]

32. Bastianetto, S.; Ramassamy, C.; Doré, S.; Christen, Y.; Poirier, J.; Quirion, R. The ginkgo biloba extract (EGb 761) protects hippocampal neurons against cell death induced by $\beta$-amyloid. Eur. J. Neurosci. 2000, 12, 1882-1890. [CrossRef] [PubMed]

33. Folin, M.; Baiguera, S.; Fioravanzo, L.; Conconi, M.T.; Grandi, C.; Nussdorfer, G.G.; Parnigotto, P.P. Caspase-8 activation and oxidative stress are involved in the cytotoxic effect of $\beta$-amyloid on rat brain microvascular endothelial cells. Int. J. Mol. Med. 2006, 17, 431-435. [CrossRef] [PubMed]

34. Ning, R.; Lei, Y.; Liu, S.; Wang, H.; Zhang, R.; Wang, W.; Zhu, Y.; Zhang, H.; Zhao, W. Natural $\beta$-dihydroagarofuran-type sesquiterpenoids as cognition-enhancing and neuroprotective agents from medicinal plants of the genus Celastrus. J. Nat. Prod. 2015, 78, 2175-2186. [CrossRef] [PubMed]

35. Behl, C.; Davis, J.; Lesley, R.; Schubert, D. Hydrogen peroxide mediates amyloid $\beta$ protein toxicity. Cell 1994, 77, 817-827. [CrossRef]

36. Paydar, M.; Wong, Y.L.; Moharam, B.A.; Wong, W.F.; Looi, C.Y. In vitro anti-oxidant and anti-cancer activity of methanolic extract from Sanchezia speciosa leaves. Pak. J. Biol. Sci. 2013, 16, 1212-1215.

37. Lu, H.; Shi, J.X.; Zhang, D.M.; Shen, J.; Lin, Y.X.; Hang, C.H.; Yin, H.X. Hemolysate-Induced expression of intercellular adhesion molecule-1 and monocyte chemoattractant protein-1 expression in cultured brain microvascular endothelial cells via through ROS-dependent NF-kB pathways. Cell. Mol. Neurobiol. 2009, 29, 87-95. [CrossRef]

(C) 2019 by the authors. Licensee MDPI, Basel, Switzerland. This article is an open access article distributed under the terms and conditions of the Creative Commons Attribution (CC BY) license (http://creativecommons.org/licenses/by/4.0/). 